\title{
THE HUMAN RIGHTS AND CIVIC EDUCATION POLICY AFTER THE CONSTITUTION AMENDMENT IN INDONESIA
}

\author{
Samsuri \\ the Yogyakarta State University (UNY), Yogyakarta, Indonesia, \\ Email: samsuri@uny.ac.id
}

\section{Abstract}

Artikel ini memaparkan perkembangan pendidikan kewarganegaraan di Indonesia pasca-1998. Sejak Presiden Soebarto mengundurkan diri pada Mei 1998, Indonesia memasuki era baru yang dikenal sebagai "era reformasi." Era ini menunjukkan basil pemberdayaan demokrasi ke dalam bentuk kebijakan kebebasan pers, desentralisasi, dan bak asasi manusia. Sebagaimana diketabui bahwa demokratisasi di Indonesia memiliki makna penting untuk kajian bak asasi manusia dan pendidikan kenarganegaraan pasca amandemen UUD 1945. Pengaturan pendidikan kewarganegaraan dalam kebijakan pendidikan nasional dalam Undang-undang No. 20 Tabun 2003 tentang Sistem Pendidikan Nasional. Pendidikan Ketvanganegaraan merupakan salab satu dari tiga mata pelajaran pokok mulai dari pendidikan anak usia dini bingga pendidikan tinggi. Hak asasi manusia dikembangken sebagai salab satu tema dalam keurikulum pendidikan kevarganegaraan. Pengajaran dan pembelajaran hak asasi manusia dalam pendidikan kevanganegaraan memiliki banyak masalab di tiap jenjang sekolah. Bias terbadap masalah-masalab bak asasi manusia, kompetensi guru, dan kondisi lokal adalab beberapa persoalan yang sedang dibadapi pendidikan kenvarganegaraan di Indonesia, meskipun amandemen UUD 1945 secara eksplisit mengakui hak asasi manusia sebagai fondasi peradaban bangsa yang demokratis.

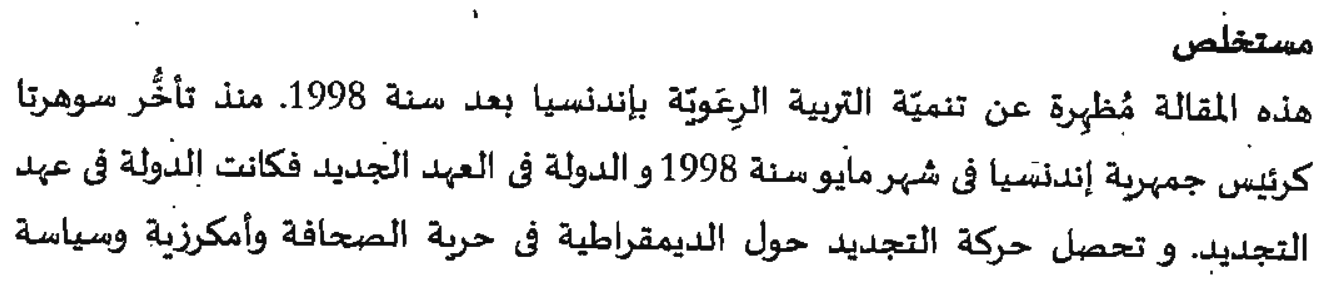


حقوق الأنسانية. كما عرقنا أن همة الديمقراطية التى لها هعنى بسبب حقوق الإنسانية وألتربية

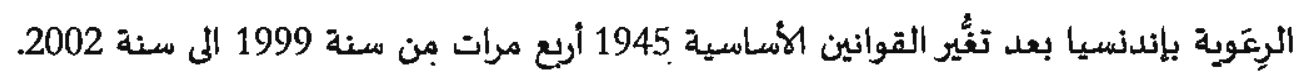
وتنظيم التبرية الرعوية فى سياسة التعليم بإندنسيا لـه مكان قوى في القوانين التوبية سينة 2003

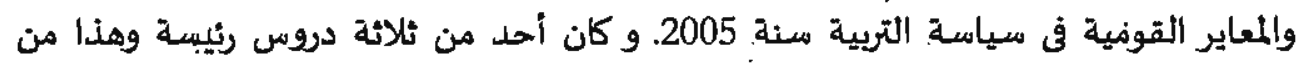

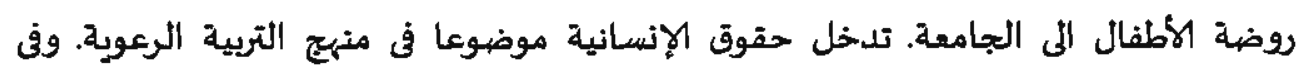

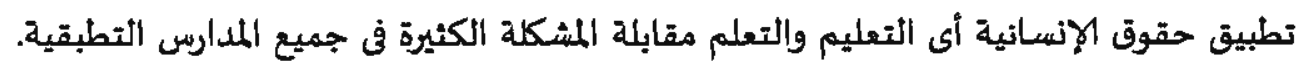

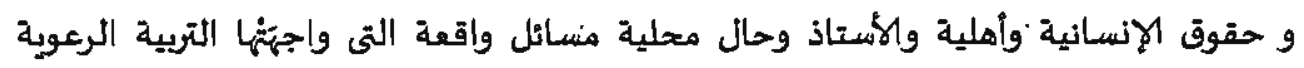

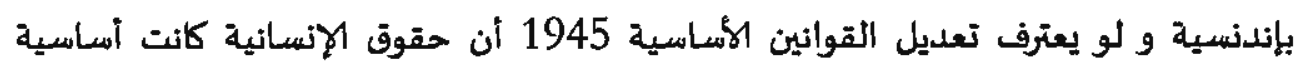
الذيمقراطية للشعب.

Keywords: Human Rights, Civic Education, Constitution, Democratization, Reformation

\section{A. Introduction}

Since the United Nations declared universally in December 10, 1948, human rights emerged as one of global issues. In Indonesia's context, the founding fathers of country put in human rights topics on the construction of constitution, later called as "Undang-Undang Dasar Tahun 1945" (Constitution of 1945). Preambule of constitution emphasized that the freedom is the rights of nations. Articles of constitution on human rights elaborated generally the meaning of the freedom.

Interpretation on the urgency of human rights has many problems in the Indonesian New Order era. The scholar noted that the human rights did not optimally being main agenda of the regime under President Soeharto. The "development" politics as big jargon of New Order extremely has often abused human rights. The citizen rights sistematically limited to support the status quo by quasi-democratic procedural, where the people choose the house people members every five years.

Indonesia has entered new era since President Soeharto resigned in May 1998. Reform movement has driven changing the horizon the country, included 
the human rights topics. Nadirsyah Hosen's study on politics and law reform on B.J. Habibie (1998-1999) administration seemed the improvement by law reforming on human tights which supported the "rule of law," and political process toward "good governance" such as anti-corruption movement.

Following the spirit of reform movement, human rights take place strongly in the constitution amendment in 2000. Beyond controversies, the People Consultation Assembly (MPR) has correctly the interpretaion of human rights according to universal principles as shown the articles of the "new" constitution.

What is relationship the human rights issues after constitution amendment for civic education in Indonesia? Civic education in the schooling program has problems when it faced the changing context post-authoritarian system. The human rights topics did not strongly characterize it as human rights education, for example.

This paper aims to explore the development of civic education in Indonesia post-1998. Specifically, I will trace the impact of constitution amendment on human rights (included the citizen rights) for the civic education developing in the education national policy.

\section{B. Human Rights for Civic Education}

Isin and Turner ${ }^{2}$ (2007) mentioned that human rights has been one of the future research agendas of citizenship studies. Other topics are "struggles for redistribution," "struggles for recognition," and "Global Citizenship versus Cosmopolitan Citizenship". This is not unreason because the human rights will be touching problems of redistribution, recognition and citizenship statuses.

Following the liberal tradition, John Patrick and Thomas S. Vontz ${ }^{3}$ emphasized the rights as one of contents of citizenship knowledge for civic

1 Nadirsyati Hosen. Reform of Indonesian Law in the Post-Soeharto Era (1998-1999), Unpublished Ph.D. Dissertation. (Unversity of Wollongong, Australia, 2003).

2 Engin F. Isin, and Bryan S. Turner. "Investigating Citizenship: An agenda for Citizenship Studies." Citizenship Studies, Vol. 11, No. 1, February 2007, pp. 5-17.

3 Patrick, John J. dan Thomas S. Vontz. "Components of Education for Democratic Citizenship in the Preparation of Social Studies Teachers," in John J. Patrick dan Robert $S$. 
education. They detailed the rights as follows: human rights/constitutional tights; political rights; personal or private rights; economic, social, cultural, and environmental rights.

This viewing paraileled with argument that human rights same as constitutional rights. In the other words, government has to protect the human rights as well as citizen rights according to constitution. Its implication, the violating of human rights has meaning against constitution. Later, Patrick and Vontz viewed international documents as known International Bill of Rights (i.e. International Covenant on Political Rights (ICPR) and International Covenant on Economic, Social, and Cultural Rights, and its additional protocols) as basic documents to civic education program.

The Intermational Commission on Education for the Tuenty-first Century of UNESCO (1996) reported that:

...[N]ot only should everyone be trained to exercise their rights and fulfil their duties, but use should be made of lifelong education in order to. build an active civil society which, occupying the middle ground between scattered individuals and a distant political authority, would enable each person to shoulder his or her share of responsibility in the community, with a view to achieving true solidarity. Thus, the education of each citizen must continue throughout his or her life and become part of the basic framework of civil society and living democracy. ${ }^{4}$

This mean that human rights in civic education has been internationally important as well as another subjects.

\section{Human Rights in Amendment of Constitution of 1945 as Core of Civic Education}

The original Constitution of 1945 has included human rights and citizen rights. Article 27 of Constitution stated that citizens has rights to equal before law, employment and living standards for humanity, and the tight and duty for

Leming, Principles and Prattices of Democracy in the Education of Social Studies Teachers, Vol. 1, (Bloomington, IN: ERIC Clearinghouse for Social Studies/Social Science Education, ERIC Clearinghouse for International Civic Education, and Civitas, 2001), p. 46.

${ }^{4}$ Jacques Delors, et al. Leaming: the Treasure IVitbin, Report to UNESCO of The International Commission on Edrcation for the Twenth-first Century, (Paris: UNESCO, 1996), p.63. 
defending of country. The rights to establish organization and expression are protected by constitition (Article 28). Unfortunately, those rights did not actualize as basic human rights as well as citizen rights in the teal-life context. New Order administration limitedly has interpretation the human rights for its interests. As character of authoritarian regime, New Order under President Soeharto dictated the meaning of human rights for all its policy.

The civic education as one of core subjects when New Order contained the values of official interpretation of Pancasila (Five Principles), which called $P$ 4 (acronym of Pedoman Penghayatan dan Pengamalan Pancasila, the Guidelines for Living and Action of Pancasila). The teaching of civic education has been reduced into values education based $P$-4. Stigma for this civic education model has relevancy with the argument of Cogan (1998) who mentioned that the power has strong influenced the citizenship education. Side effect of this policy, civic education could be taught by all teacher, although civic educators have been produced by civic education department at IKIP (Institut Keguruan dan Ilmu Pendidikan). Related the human rights, contents of civic education relatively limited to explore the principles of human rights according to universal principles. Its reasoning that Indonesia has concept the human rights before international community released the Universal Declaration of Human Rights (UDHR) in 1948. Constitution 1945 has enough articles on human rights.

Reform movement in Indonesia since the fallen of President Soeharto has driven the MPR (People Consultation Assembly) to amendment the Constitution 1945. The Constitution 1945 has been sacred as long as New Order period. The effort to interpretation of Constitution 1945 assumed as rebellion, subversive movement, or against constitution itself.

Human rights have been recognized strongly within Constitution 1945 amended. The "new" Constitution derived the human rights in Chapter XA following to universal principles of UDHR. Detailed of human rights according to "new" Constitution has been explained at Article 28A through Article 28J. It's interesting and paradox that MPR did the "copy paste" for all articles related human rights in Human Rights Act of 1999 (UU RI No. 39 Tahun 1999). 
Amended Constitution 1945 has influenced all field of living nation. The education national reformed. Democratization and decentralization became main agendas to reform education national system as arranged by Education National System Act in $1989^{\circ}$ (UU RI No. 2 Tahun 1989).

Regulating civic education in the Indonesia educational policy has strong position in the Education National System Act in 2003 and the National Standard of Education Policy in 2005, which it has been one of three core subjects (i.e. religious education, civic education and language) from kindergarten classes through university. Education Act (2003) stated that civic education has to be taught at all levels, included for all Indonesian citizens who studied at all foreign education institution at primary and secondary levels (Article 65 Part (2)).

According to Regulation of Ministry of National Education (MONE) in 2006 on Content Standards, civic education aimed to build students have ability to:

1. think critically, rational, creative to respond the citizenship issues;

2. participate actively and responsibility, and action smartly to public affairs and anti-corruption movement;

3. develop positively and democratic to build him/herself according to Indonesian characters to living together with other nations.

4. interact with other nation around the world and use information and communication technology both directly and indirectly. ${ }^{5}$

That aims above have similarity with the components of civic competencies which be developed by the Center for Civic Education (1994) at Calabasas, California, United States of America. The Center divided the civic competencies which be mastered by students as follows: Citic Knowledge, Civic Skills (i.e. intellectual and participatory skills), and Civic Dispositions (Branson, 1998, Center for Civic Education, 1994). The Center has produced a document which be content standards for teach the civic education nationally in USA, which called as The National Standards for Civics and Government. For some

${ }^{5}$ See the Attachment of Regulation of MONE, No. 22 Year 2006 on the Standardization on Contents of subjects at the Primary and Secondary Education Levels. 
academicians, that civic education called as "new civic education paradigm" to differ civic education which developed in the New Order period. ${ }^{6}$.

That is not surprising, because developing civic education post-1998 in Indonesia has been influenced academically by CCE. Some activities which hold by Center for Indonesian Civic Education (CICED), a non-governmental organization based Bandung and majority lead by IKIP Bandung academicians (now Indonesia University of Education, UPD), since last 1990s until 2001 has influenced discourses and policy on civic education reform. In July 2001 Yogyakarta State University (YSU) and CICED hold international seminar on tolerance and human rights education. That event was important to develop human rights issue as one core of civic education contents forward.

According to Regulation of MONE on Content Standards in 2006 (Permendiknas RI No. 22 Tahun 2006), topics of civic education curriculum are unity of nation; norms and laws; human tights; need of citizens; constitution; power and politics; Pancasila; and, globalization. Theme of human rights contained the issues on right and duty of children, right and duty of community; national and international instruments of human .rights; and supporting and respecting of human rights. The topic is taught at seventh class of secondary school level.

Regulation of MONE Number 23 Year 2006 stated parameters on Graduated Competency Standards for all subjects. Related to human rights topic in civic education, students at primary and secondary school should able to "understand the obligation as member of family and school." At the high senior school, students should able to "analysis the patterns and participate actively to support, respect, and enforcement of human rights both domestic an abroad," and then "analysis role and citizen rights in government system of Republic of Indonesia."7

6 See Muchson. "Pendidikan Kewarganegaraan Paradigma Baru dan Implementasinya dalam Kurikulum Berbasis Kompetensi". Jumal Civios, Vol. 1, No. 1, Juni 2004, pp. 29-41; and, Cholisin. "Konsolidasi Demokrasi Melalui Pengembangan Karakter Kewarganegaraan," Jumal Civies, Vol 1, No. 1, Juni 2004, pp. 14-28

7 See the Attachment of Regulation of MONE, No. 23 Year 2006 on the Standardization of Outcome Competency. 


\section{Closing Remarks}

Reform movement post-1998 has opened opportunity to national recovery for all fields. Amendment of Constitution 1945 has characterized the grand design to reform the national living future.

Human rights as well as citizen rights became heart of "new" Constitution 1945. The urgency of human rights within constitution has taken place very important into civic education reform. As known, "old" civic education in the New Order period has been used as a tool of regime to dictate "official interpretation" on Pancasila. Human rights as one of core topics of civic education often assumed as "western values" and then it meant contradiction with Pancasila as way of life of nation.

Human tights topic formally has been accepted as a content of "new" civic education. This condition is not without problem. Standardizations both contents and competencies required smart teachers to arranged great vision and mission of civic education build good and smart citizen. Human rights as great theme, off course, need "great teachers" who able to transform the ideas of human rights to their students became future citizen as well as humanist. The biases on human rights issues (i.e. based religion or cultural views), teacher competencies, and local conditions are some problems will be faced the civic education in Indonesia the next. The goals of human rights education into civic education will be achieved to build democratic citizens, if teachers and all components (school climates, social environment and family) conducive to inculcate and apply human rights values as real learning daily.

\section{REFERENCES}

Bourchier, David. 2007. Pancasila Versi Orde Baru dan Asal Muasal Negara Organis .. (Integralistik), tran. Agus Wahyudi from dissertation in English, Lineages of Onganicist Political Thought in Indonesia. Yogyakarta: Aditya Media Yogyakarta and Pusat Studi Pancasila Universitas Gadjah Mada. 
Cholisin. 2004. "Konsolidasi Demokrasi Melalui Pengembangan Karakter Kewarganegaraan," Jumal Civics, Vol. 1, No. 1, Juni, pp. 14-28

Delors, Jacques., et al. 1996. Learning: the Treasure Within, Report to UNESCO of The International Commission on Education for the Twenty-first Century, Paris: UNESCO

Fakih, Mansour, Indrianto, A.M., Prasetyo, Eko. 2003. Menegakkan Keadilan dan Kemanusian: 'Pegangan untuk Membangun Gerakan Hak Asasi Manusia. Yogyakarta: Insist Press and Pustaka Pelajar

Hosen, Nadirsyah. 2003. Reform of Indonesian Law in the Post-Soeharto Era (19981999), Unpublished Ph.D. Dissertation. Unversity of Wollongong, Australia

Isin, Engin. F.; and Turner, Bryan S. 2007. "Investigating Citizenship: An agenda for Citizenship Studies." Citizenship Studies, Vol. 11, No. 1, February, pp. 5-17.

Muchson. 2004. "Pendidikan Kewarganegaraan Paradigma Baru dan Implementasinya dalam Kurikulum Berbasis Kompetensi'”. Jumal Civics, Vol. 1, No. 1, Juni, pp. 29-41

Patrick, John J. and Thomas S. Vontz. 2001. "Components of Education for Democratic Citizenship in the Preparation of Social Studies Teachers," in John J. Patrick dan Robert S. Leming, Principles and Practices of Democracy in the Education of Social Studies Teachers, Vol. 1, Bloomington, IN: ERIC Clearinghouse for Social Studies/Social Science Education, ERIC Clearinghouse for International Civic Education, and Civitas, pp. 39-64

Peraturan Pemerintab Republik Indonesia No. 19 Tabun 2005 tentang Standar Nasional Pendidikan

Republic of Indonesia. 2006. Regulation of MONE, No. 23 Year 2006 on the Standardization of Outcome Competeng. Attachment. (Permendiknas RI No. 23 Tabun 2006 tentang Standar Kompetensi Lalusan. Untuk Satuan Pendidikan Dasar dan Menengab. Lampiran)

Republic of Indonesia. 2006. Regulation of MONE, No. 22 Year 2006 on the Standardization on Contents of subjects at the Primary and Secondary Education 
264 Millab Vol. XII, No.1, Agustus 2012

Levels. Attachments (Permendiknas RI No. 22 Tahun 2006 tentang' Standar Isi Untuk Satuan Pendidikan Dasar dan Menengah. Lampiran)

Republic of Indonesia. 1989. Education National System Act No. 2 Year 1989.

Republic of Indonesia.1999. Human Rights Act No. 39 Year 1999.

Republic of Indonesia. 2003. Education National System Act No. 20 Year 2003

Samsuri. 2004. "Civic Virtues dalam Pendidikan Motal dan Kewarganegaraan di Indonesia Era Orde Baru." Jumal Civics, Vol. 1, No. 2, December, pp. 224 239. 